\title{
Gambaran Hematologi pada Wanita Hamil Trimester 3 yang Terkonfirmasi Positif SARS-CoV-2 di RSUP Prof. Dr. R.D. Kandou Periode Juli-September 2020
}

\author{
Fibriani F. Manopo, ${ }^{1}$ Siemona L. E. Berhimpon, ${ }^{2}$ Mayer F. Wowor ${ }^{2}$
}

\author{
${ }^{1}$ Program Studi Pendidikan Dokter Fakultas Kedokteran Universitas Sam Ratulangi, \\ Manado, Indonesia \\ ${ }^{2}$ Bagian Patologi Klinik Fakultas Kedokteran Universitas Sam Ratulangi, Manado, \\ Indonesia \\ Email: feybimanopo99@gmail.com
}

\begin{abstract}
Pregnancy is a condition of physiological and mechanical changes in the body that can reduce the ability of the immune system. During pregnancy, the normal changes that occur can be observed on the hematological index. There are studies that have found decreased levels of lymphocytes and monocytes, total leukocytes, increased platelet counts, and increased $\mathrm{Hb}$ in pregnant women infected with SARS-CoV-2. This study aimed to determine an overview of leucocytes, differential counting and platelets in $3^{\text {rd }}$ trimester pregnant women. This research is a descriptive type of retrospective study, by collecting secondary data from medical record status. There were 26 samples of pregnant women in trimester 3 who were confirmed positive for SARS-CoV-2, 17 patients (65\%) had an increase in the number of leukocytes. Differential counting was decreased stem neutrophils in 13 patients (50\%), normal segment neutrophils in 16 patients $(62 \%)$, decreased lymphocytes in 13 patients $(50 \%)$, decreased eosinophils in 14 patients (54\%), monocytes increased only in 2 patients $(8 \%)$ and basophils were normal in all patients. $100 \%$ normal platelet count in all samples. In conclusion, the hematological features obtained are leukocytosis, decreased stem neutrophils, $62 \%$ normal segment neutrophils, lymphopenia, eosinopenia. normal $92 \%$ monocytes are normal, basophils and platelets within normal limits.
\end{abstract}

Keywords: SARS-CoV-2, pregnant women, leukocytes, differential counting, thrombocyte

\begin{abstract}
Abstrak: Kehamilan merupakan suatu kondisi perubahan fisiologis dan mekanis tubuh yang dapat berdampak pada penurunan kemampuan sistem kekebalan tubuh. Selama kehamilan, perubahan normal yang terjadi dapat diamati pada indeks hematologi. Terdapat penelitian yang menemukan penurunan kadar limfosit dan monosit, total leukosit, peningkatan jumlah trombosit, dan peningkatan $\mathrm{Hb}$ pada wanita hamil yang terinfeksi SARS-CoV-2. Tujuan penelitian ini untuk mengetahui gambaran leukosit, differential counting dan trombosit pada wanita hamil trimester 3. Penelitian ini merupakan jenis penelitian deskriptif dengan studi retrospektif, yaitu dengan mengumpulkan data sekunder berupa data dari status rekam medik. Terdapat 26 sampel wanita hamil trimester 3 yang terkonfirmasi positif SARS-CoV-2, 17 pasien $(65 \%)$ mengalami peningkatan jumlah leukosit. Differential counting yaitu neutrofil batang menurun pada 13 pasien (50\%), neutrofil segmen normal pada 16 pasien $(62 \%)$, limfosit menurun pada 13 pasien $(50 \%)$, eosinofil menurun pada 14 pasien $(54 \%)$, monosit meningkat hanya pada 2 pasien $(8 \%)$ dan basofil dalam jumlah normal pada semua pasien. Jumlah trombosit $100 \%$ normal pada semua sampel. Sebagai simpulan, gambaran hematologi yang didapatkan yaitu leukositosis, penurunan neutrofil batang, neutrofil segmen $62 \%$ normal, limfopenia, eosinopenia. monosit 92\% normal, basofil dan trombosit dalam batas normal.
\end{abstract}

Kata kunci : SARS-CoV-2, wanita hamil, leukosit, differential counting, trombosit 


\section{PENDAHULUAN}

Desember 2019 di kota Wuhan, Cina telah ditemukan kasus pneumonia yang tidak diketahui etiologinya. Penyakit ini menyebar sangat cepat ke seluruh provinsi di Cina serta negara lain seperti Thailand, Jepang, dan Korea Selatan yang membutuhkan waktu kurang dari satu bulan. Melalui sampel yang diteliti didapatkan bahwa penyebab penyakit tersebut adalah jenis coronavirus baru. Awalnya penyakit tersebut dinamakan 2019 novel coronavirus (2019-nCoV) kemudian World Health Organization (WHO) mengumumkan penyakit ini dengan nama baru pada tanggal 11 Februari 2020 sebagai Coronavirus Disease 2019 (COVID-19) yang disebabkan oleh virus Severe Acute Respiratory Syndrome Coronavirus-2 (SARS-CoV-2). ${ }^{1}$

Orang yang terinfeksi SARS-CoV-2 $80 \%$ tidak bergejala maupun dengan gejala ringan (mild), 15\% sedang (severe) yang membutuhkan oksigen, dan $5 \%$ berat yang membutuhkan ventilator. ${ }^{2}$ Risiko terjadi komplikasi bahkan kematian dari COVID19 meningkat pada beberapa populasi. Kelompok yang dikategorikan rentan yaitu lanjut usia, kehamilan, individu yang menderita kelemahan, atau yang memiliki beberapa kondisi kronis seperti, memiliki diabetes, penyakit jantung, penyakit paru menahun, kanker, gangguan imunitas tubuh, masalah pembekuan darah, atau yang mengarah pada kondisi sepsis. ${ }^{3,4}$

Kehamilan merupakan suatu kondisi perubahan fisiologis dan mekanis tubuh yang dapat berdampak pada penurunan kemampuan sistem kekebalan tubuh. ${ }^{3,5}$ Adanya penurunan sistem imunitas menyebabkan peningkatan risiko untuk terinfeksi secara umum. ${ }^{2}$ Saat ini sudah mulai banyak data mengenai Covid-19 tetapi informasi mengenai kehamilan dengan Covid-19 masih terbatas. ${ }^{5}$

Tes laboratorium seperti pemeriksaan hematologi berperan penting sebagai penyaring pasien yang berpotensi mengarah ke COVID-19, terutama pada daerah yang belum mempunyai fasilitas RT-PCR serta dapat mengidentifikasi pasien yang berisiko mengalami komplikasi dan menentukan intervensi pengobatan/ tindakan medis pada pasien yang sudah terkonfirmasi positif COVID19. Perubahan hematologi seperti pada leukosit (limfosit, eosinofil, neutrofil) dapat menggambarkan proses infeksius atau untuk menunjukkan kecurigaan tingkat keparahannya. ${ }^{6}$ Selain itu, komplikasi trombotik pada pasien dengan COVID-19 sering terjadi dan berkontribusi pada kegagalan dan kematian organ sehingga sangat penting untuk dilakukan pemeriksaan dan pemantauan terhadap trombosit. ${ }^{7}$

Kelompok wanita hamil trimester 3 yang terkonfirmasi COVID-19 merupakan sasaran utama dalam penelitian, karena kondisi kehamilan sangat rentan mengalami infeksi. ${ }^{2}$ Berbagai perubahan parameter hematologi dapat memberikan informasi dalam membantu mengidentifikasi pasien COVID-19, pasien yang berisiko mengalami komplikasi dan dapat menentukan tindakan/pengobatan sehingga merupakan informasi yang sangat penting di masa pandemi ini serta data COVID-19 pada wanita hamil yang ada saat ini masih kurang.

\section{METODE PENELITIAN}

Penelitian ini merupakan jenis penelitian deskriptif dengan studi retrospektif, yaitu dengan mengumpulkan data sekunder berupa data dari status rekam medik pasien dan mengolahnya kembali. Kriteria inklusi dalam menentukan sampel yaitu pasien yang tercatat di rekam medik RSUP Prof. Dr. R. D. Kandou, wanita hamil trimester 3, pasien terkonfirmasi SARS-CoV-2 dengan RT-PCR, memiliki hasil pemeriksaan hematologi (jumlah leukosit, differential counting, dan trombosit).

\section{HASIL PENELITIAN}

Penelitian dilaksanakan di Instalasi rekam medik RSUP. Prof. Dr. R. D. Kandou dan terdapat 26 sampel wanita hamil trimester 3 yang terkonfirmasi positif 
SARS-CoV-2 dengan pemeriksaan PCR pada bulan Juli - September tahun 2020.

Tabel 1. Distribusi Pasien Berdasarkan Usia

\begin{tabular}{ccc}
\hline Golongan Usia & $\begin{array}{c}\text { Jumlah } \\
\text { Pasien }\end{array}$ & Presentase \\
\hline$<20$ tahun & 1 & $4 \%$ \\
$20-35$ tahun & 20 & $77 \%$ \\
$>35$ tahun & 5 & $19 \%$ \\
Total & 26 & $100 \%$ \\
\hline
\end{tabular}

Tabel 2. Distribusi Pasien dengan Gejala dan Tanpa Gejala

\begin{tabular}{ccc}
\hline Kategori & Jumlah & Presentase \\
\hline Bergejala & 19 & $73 \%$ \\
Tanpa gejala & 7 & $27 \%$ \\
Total & 26 & $100 \%$ \\
\hline
\end{tabular}

Tabel 3. Gambaran Leukosit Wanita Hamil

\begin{tabular}{ccc}
\hline Pasien & $\begin{array}{c}\text { Jumlah } \\
\text { Leukosit (4,0 } \\
-\mathbf{1 0 , 0} \mathbf{x} \\
\mathbf{1 0} \text { / } \mathbf{\mu L})\end{array}$ & Keterangan \\
\hline Pasien 1 & 22,8 & Meningkat \\
Pasien 2 & 7,3 & Normal \\
Pasien 3 & 12,4 & Meningkat \\
Pasien 4 & 29,1 & Meningkat \\
Pasien 5 & 6,1 & Normal \\
Pasien 6 & 13,2 & Meningkat \\
Pasien 7 & 13,7 & Meningkat \\
Pasien 8 & 8,3 & Normal \\
Pasien 9 & 12,1 & Meningkat \\
Pasien 10 & 11,9 & Meningkat \\
Pasien 11 & 13,7 & Meningkat \\
Pasien 12 & 8,3 & Normal \\
Pasien 13 & 12,1 & Meningkat \\
Pasien 14 & 11,9 & Meningkat \\
Pasien 15 & 8,0 & Normal \\
Pasien 16 & 11,0 & Meningkat \\
Pasien 17 & 11,0 & Meningkat \\
Pasien 18 & 23,9 & Meningkat \\
Pasien 19 & 17,2 & Meningkat \\
Pasien 20 & 11,6 & Meningkat \\
Pasien 21 & 11,0 & Meningkat \\
Pasien 22 & 9,7 & Normal \\
Pasien 23 & 6,0 & Normal \\
Pasien 24 & 10,2 & Meningkat \\
Pasien 25 & 9,3 & Normal \\
Pasien 26 & 6,9 & Normal \\
\hline
\end{tabular}

Distribusi usia terendah didapatkan yaitu 15 tahun dan untuk usia tertinggi yaitu 41 tahun (Tabel 1). Gejala yang paling sering dikeluhkan oleh pasien adalah demam/ riwayat demam, batuk, sesak napas, dan pilek (Tabel 2)

Nilai tertinggi dari leukosit yang didapatkan pada wanita hamil trimester 3 yaitu 29,1 x $10^{3} / \mu \mathrm{L}$ sedangkan hasil terendah nilai leukosit adalah $6,0 \times 10^{3} / \mu \mathrm{L}$ (Tabel 3)

Tabel 4. Gambaran Differential Counting Wanita Hamil

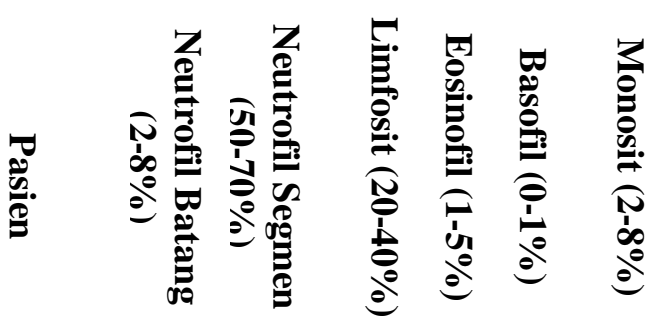

\begin{tabular}{lcccccc}
\hline Pasien 1 & 14 & 69 & 12 & 0 & 0 & 5 \\
Pasien 2 & 3 & 67 & 20 & 3 & 0 & 7 \\
Pasien 3 & 8 & 60 & 26 & 1 & 0 & 5 \\
Pasien 4 & 8 & 80 & 4 & 0 & 0 & 8 \\
Pasien 5 & 1 & 71 & 19 & 1 & 0 & 8 \\
Pasien 6 & 4 & 71 & 16 & 3 & 0 & 6 \\
Pasien 7 & 0 & 73 & 20 & 0 & 0 & 7 \\
Pasien 8 & 9 & 61 & 22 & 0 & 0 & 8 \\
Pasien 9 & 11 & 66 & 19 & 0 & 0 & 4 \\
Pasien 10 & 1 & 84 & 8 & 0 & 0 & 7 \\
Pasien 11 & 2 & 78 & 13 & 0 & 0 & 7 \\
Pasien 12 & 0 & 63 & 29 & 1 & 0 & 7 \\
Pasien 13 & 1 & 73 & 18 & 0 & 0 & 8 \\
Pasien 14 & 7 & 63 & 21 & 2 & 0 & 7 \\
Pasien 15 & 7 & 56 & 31 & 0 & 0 & 6 \\
Pasien 16 & 0 & 78 & 17 & 0 & 0 & 5 \\
Pasien 17 & 0 & 67 & 22 & 0 & 0 & 11 \\
Pasien 18 & 16 & 65 & 13 & 0 & 0 & 6 \\
Pasien 19 & 0 & 78 & 16 & 0 & 0 & 6 \\
Pasien 20 & 0 & 75 & 18 & 2 & 0 & 5 \\
Pasien 21 & 5 & 69 & 23 & 0 & 0 & 3 \\
Pasien 22 & 0 & 66 & 24 & 1 & 0 & 9 \\
Pasien 23 & 0 & 54 & 37 & 4 & 0 & 5 \\
Pasien 24 & 0 & 54 & 39 & 1 & 0 & 6 \\
Pasien 25 & 3 & 70 & 18 & 2 & 0 & 7 \\
Pasien 26 & 0 & 63 & 29 & 1 & 0 & 7 \\
\hline
\end{tabular}


Pada tabel 4 didapatkan untuk jumlah neutrofil batang 13 pasien (50\%) menurun, 4 pasien (15\%) mengalami peningkatan, dan 9 pasien (35\%) dalam kategori normal. Neutrofil segmen pada 10 pasien (38\%) mengalami peningkatan dan 16 pasien (62\%) lainnya berada pada nilai normal. Nilai tertinggi neutrofil segmen yaitu $84 \%$ dan yang terendah $54 \%$. Hasil limfosit pada 13 pasien $(50 \%)$ mengalami penurunan dan sisanya 13 pasien $(50 \%)$ berada pada nilai normal. Jumlah Eosinofil didapatkan pada 14 pasien $(54 \%)$ menurun dan 12 pasien (46\%) lainnya pada kategori normal. Hasil eosinofil tertinggi yang didapatkan yaitu $4 \%$ dan yang terendah $0 \%$. Nilai basofil pada semua wanita hamil didapatkan $100 \%$ dalam nilai normal. Jumlah monosit pada 2 pasien (8\%) mengalami peningkatan dan 24 pasien $(92 \%)$ tidak ditemukan kelainan.

Tabel 5. Gambaran trombosit wanita hamil

\begin{tabular}{ccc}
\hline Pasien & $\begin{array}{c}\text { Jumlah } \\
\text { Trombosit } \\
(\mathbf{1 5 0 - 4 5 0} \mathbf{x} \\
\mathbf{1 0} \text { / } \boldsymbol{\mu L} \mathbf{\text { }})\end{array}$ & Keterangan \\
\hline Pasien 1 & 190 & Normal \\
Pasien 2 & 319 & Normal \\
Pasien 3 & 346 & Normal \\
Pasien 4 & 214 & Normal \\
Pasien 5 & 282 & Normal \\
Pasien 6 & 253 & Normal \\
Pasien 7 & 256 & Normal \\
Pasien 8 & 267 & Normal \\
Pasien 9 & 252 & Normal \\
Pasien 10 & 204 & Normal \\
Pasien 11 & 181 & Normal \\
Pasien 12 & 340 & Normal \\
Pasien 13 & 229 & Normal \\
Pasien 14 & 245 & Normal \\
Pasien 15 & 207 & Normal \\
Pasien 16 & 241 & Normal \\
Pasien 17 & 407 & Normal \\
Pasien 18 & 301 & Normal \\
Pasien 19 & 268 & Normal \\
Pasien 20 & 312 & Normal \\
Pasien 21 & 282 & Normal \\
Pasien 22 & 246 & Normal \\
Pasien 23 & 348 & Normal \\
Pasien 24 & 270 & Normal \\
Pasien 25 & 289 & Normal \\
Pasien 26 & 230 & Normal \\
\hline & & \\
\hline
\end{tabular}

Tabel 5 didapatkan nilai trombosit pada semua wanita hamil trimester 3 berada pada nilai normal. Pada penelitian ini jumlah trombosit tertinggi yaitu $407 \mathrm{x}$ $10^{3} / \mu \mathrm{L}$ sedangkan yang terendah adalah $181 \times 10^{3} / \mu \mathrm{L}$

\section{BAHASAN}

Dari hasil penelitian melalui pengumpulan data hematologi wanita hamil trimester 3 yang terkonfirmasi positif COVID-19 pada bulan Juli- September tahun 2020 yang dilakukan di RSUP. Prof. Dr. R. D. Kandou, didapatkan 26 wanita hamil yang memenuhi kriteria inklusi. Jumlah leukosit pada 17 pasien (65\%) wanita hamil trimester 3 yang terkonfirmasi SARS-CoV-2 dengan RT-PCR menunjukkan terjadinya leukositosis. Menurut Zhang dkk yang melakukan penelitian terhadap 18 wanita hamil trimester 3 di rumah sakit Renmin, Wuhan didapatkan 7 wanita hamil (39\%) mengalami peningkatan jumlah leukosit. ${ }^{8}$ Penelitian yang dilaksanakan juga selaras dengan hasil Systematic review dari 48 literatur oleh Chamseddine dkk yang menyatakan abnormalitas paling sering ditemukan salah satunya adalah leukositosis. ${ }^{9}$ Leukositosis normal dapat terjadi pada wanita hamil dengan atau tanpa COVID-19, akibat peningkatan respon inflamasi yang merupakan adaptasi dari imun tubuh dan imunomodulasi dari janin. $^{10}$

Hasil neutrofil batang pada penelitian didapatkan paling banyak 13 pasien (50\%) menurun, sedangkan neutrofil segmen pada 10 pasien $(38 \%)$ mengalami peningkatan dan 16 pasien (62\%) berada pada nilai normal. Menurut Chamseddine dkk dalam Systematic review ditemukan yaitu peningkatan neutrofil atau disebut neutrofilia. ${ }^{9}$ Berdasarkan penelitian yang dilakukan Yan dkk tidak mendapatkan abnormalitas pada nilai neutrofil. ${ }^{11}$ Neutrofilia dapat mengindikasikan terjadi infeksi virus, parasit, perdarahan sampai gangguan myeloproliferatif. ${ }^{12}$ Gambaran limfosit dalam penelitian melalui data rekam medik yaitu $50 \%$ mengalami 
penurunan atau limfopenia. Menurut Sasson dkk yang melakukan penelitian terhadap wanita hamil menemukan $45,5 \%$ mengalami limfositopenia. ${ }^{13}$ Penurunan limfosit dapat disebabkan oleh virus HIV (Human Immunodeficiency Virus) yang merusak sel T (CD4), anemia aplastik, luka bakar, dan trauma. ${ }^{12,14}$ Nilai eosinofil yang di dapatkan pada 14 pasien (54\%) mengalami penurunan, demikian penelitian yang dilakukan Sun dkk terhadap 116 pasien Covid-19 yaitu pemeriksaan darah tepi rutin didapatkan jumlah eosinofil di bawah angka normal. ${ }^{15}$ Jumlah basofil $100 \%$ masuk dalam kategori yang normal, berbeda dengan penelitian yang dilakukan oleh Sun dkk yang menemukan penurunan signifikan terhadap limfosit, eosinofil, dan basofil. ${ }^{16}$ Jenis leukosit terakhir yang diteliti yaitu monosit, yang menunjukkan hasil pada 2 pasien (8\%) mengalami peningkatan dan 24 pasien $(92 \%)$ tidak ditemukan kelainan. Studi yang dilakukan oleh Sasson dkk terhadap 11 wanita hamil menemukan monosit dalam keadaan normal. $^{13}$ Penurunan monosit sering diakibatkan oleh penggunaan glukokortikoid, stress, anemia aplastik. Monositosis dapat dikatakan normal terjadi selama kehamilan. ${ }^{14}$

Gambaran trombosit yang didapatkan pada penelitian ini $100 \%$ dalam keadaan normal. Hasil serupa didapatkan pada penelitian terhadap 11 wanita hamil dan 25 yang tidak hamil di University-affiliated tertiary medical center menemukan nilai normal terhadap WBC, hemoglobin, dan trombosit. ${ }^{13}$ Pada kehamilan dapat terjadi penurunan trombosit secara signifikan akibat dinding rahim yang berkembang untuk kompensasi pertumbuhan janin maka dapat terjadi laserasi di pembuluh darah yang menyebabkan perdarahan masif. Dapat dikatakan bahwa trombositopenia dapat terjadi pada kehamilan normal meskipun tidak terinfeksi SARS-CoV-2 dan sebagai indikator penting terhadap tingkat keparahan COVID-19 14,17

\section{SIMPULAN}

Jumlah leukosit pada wanita hamil trimester 3 yang terkonfirmasi SARS-CoV2 paling banyak mengalami leukositosis. Gambaran differential counting pada wanita hamil trimester 3 yang terkonfirmasi SARS-CoV-2 yaitu neutrofil batang 50\% menurun, neutrofil segmen $62 \%$ normal, limfosit dan eosinofil masing-masing menurun atau disebut juga limfopenia dan eosinopenia, basofil semua dalam nilai normal, monosit meningkat hanya $8 \%$. Nilai trombosit pada wanita hamil trimester 3 tidak ditemukan adanya kelainan, semua dalam nilai normal.

\section{Konflik Kepentingan}

Penulis menyatakan tidak terdapat konflik kepentingan dalam studi ini.

\section{DAFTAR PUSTAKA}

1. Susilo A, Rumende CM, Pitoyo CW, Santoso WD, Yulianti M, Herikurniawan $\mathrm{H}$, et al. Coronavirus Disease 2019: Tinjauan Literatur Terkini. Jurnal Penyakit Dalam Indones. 2020;7(1):45.

2. Rohmah MK, Nurdianto AR. Corona Virus Disease 2019 ( COVID-19 ) pada Wanita Hamil dan Bayi: Sebuah Tinjauan Literatur. 2020;7(1A):329-36.

3. Akbar A. Gejala Klinis Infeksi Virus Corona 2019 (COVID-19) Pada Wanita Hamil. Jurnal Implementa Husada 2020;1(2):172-80.

4. Pradana AA, Casman C, Nur'aini N. Pengaruh Kebijakan Social Distancing pada Wabah COVID19 terhadap Kelompok Rentan di Indonesia. Jurnal Kebijakan Kesehatan Indonesia JKKI. 2020; 9(2):61-7. Available from: https://jurnal.ugm.ac.id/jkki/article /view/55575

5. Noelle B, Caitlin B, Cynthia G-B, Russell M, Rebecca M. Coronavirus Disease 2019 infection among asymptomatic 
and symptomatic pregnant women: two weeks of confirmed presentations to an affiliated pair of New York City hospitals. Elsevier. 2020;(January):1-7.

6. Letícia S, Toledo DO, Nogueira LS, Carvalho G. COVID-19: Review and hematologic impact. Clin Chim Acta. 2020;510(January): 170-6.

7. Manne BK, Denorme F, Middleton EA, Portier I, Rowley JW, Stubben C, et al. Platelet gene expression and function in patients with COVID19. Blood. 2020;136(11):1317-29.

8. Zhang L, Dong L, Ming L, Wei M, Li J, $\mathrm{Hu} \mathrm{R}$, et al. Severe Acute Respiratory Syndrome Coronavirus 2(SARS-CoV-2) infection during late pregnancy: A Report of 18 patients from Wuhan, China. BMC Pregnancy and Childbirth 2020;20(394):1-7.

9. Chamseddine RS, Wahbeh F, Chervenak F, Salomon LJ, Ahmed B, Rafii A. Pregnancy and Neonatal Outcomes in SARS-CoV-2 Infection: A Systematic Review. J Pregnancy. 2020; (October) 2020: 1-7.

10. Osonuga IO, Osonuga OA, Onadeko AA, Osonuga A, Osonuga AA. Hematological profile of pregnant women in southwest of Nigeria. Asian Pacific J Trop Dis. 2011;1(3):232-4.
11. Yan J, Guo J, Fan C, Juan, Yu X, Li J, et al. Coronavirus disease 2019 in pregnant women: a report based on 116 cases. Am J Obstet Gynecol. 2020;2507(1):1-9.

12. Kementerian Kesehatan RI. Pedoman Interpretasi Data Klinis. 2011; (January):1-83.

13. Mohr-Sasson A, Chayo J, Bart Y, Meyer R, Sivan E, Mazaki-Tovi S, et al. Laboratory characteristics of pregnant compared to nonpregnant women infected with SARS-CoV-2. Arch Gynecol Obstet. 2020;302(3):629-34.

14. Mutua DN, Njagi ENM, Owino Orinda G. Hematological Profile of Normal Pregnant Women. J Blood Lymph. 2018;8(2).1-6

15. Abnormalities of peripheral blood system in patients with COVID-19 in Wenzhou, China. Clin Chim Acta. 2020;507(January):174-80.

16. Sun D, Zhang D, Tian R, Li Y, Wang $\mathrm{Y}$, Cao $\mathrm{J}$, et al. The underlying changes and predicting role of peripheral blood inflammatory cells in severe COVID-19 patients: A sentinel. Clin Chim Acta. 2020;508(January):122-9.

17. Frater JL, Zini G, d'Onofrio G, Rogers HJ. COVID-19 and the clinical hematology laboratory. Int $\mathrm{J}$ Lab Hematol. 2020;42(S1):11-8. 